\title{
KEWENANGAN POLRI DALAM MENEGAKKAN KODE ETIK ANGGOTA POLRI YANG MELAKUKAN TINDAK PIDANA NARKOBA
}

\author{
Doddy Kristian, Bambang Sadono, Kadi Sukarna, Diah Sulistyani RS \\ Magister Hukum Universitas Semarang, Semarang \\ kristiandoddy800@gmail.com
}

\begin{abstract}
Abstrak
Tujuan penelitian ini adalah untuk mengkaji kewenangan Polri dalam menegakkan Kode Etik Kepolisian yang melakukan tindak pidana Narkoba suatu kajian Peraturan Kapolri No. 14 Tahun 2011 Tentang Kode Etik Kepolisian dan bagaimana reposisi kewenangan Polri dalam menegakkan kode etik anggota Kepolisian yang melakukan tindak pidana Narkoba suatu kajian Peraturan Kapolri No. 14 Tahun 2011 Tentang Kode Etik Kepolisian. Metode dalam penelitian ini menggunakan metode penelitian deskriptif kualitatif dengan pendekatan yuridis normatif. Hasil penelitian ini adalah Kode Etik Kepolisian sebagaimana diatur dalam Peraturan Kapolri Nomor 14 Tahun 2011 sudah berfungsi terhadap anggota kepolisian selaku aparat penegak hukum. Sehingga dengan berfungsinya kode etik kepolisian tersebut maka bisa menekan pelanggaran-pelanggaran terhadap kode etik kepolisian yang berkaitan dengan etika kenegaraan, etika kelembagaan, etika kemasyarakatan dan etika kepribadian.dan setiap anggota kepolisian tersebut harus tunduk. Kewenangan Kepolisian Daerah Jawa Tengah dalam menegakkan Kode Etik Kepolisian yang melakukan tindak pidana Narkoba melalui sidang kode etik dan apabila terbukti dilakukan peradilan umum serta pemecatan dari dinas kepolisian apabila terbukti melakukan tindak pidana Narkoba. Reposisi terhadap penegakan hukum terhadap anggota Kepolisian yang melanggar kode etik dengan melakukan tindak pidana Narkoba, Kepolisian Daerah Jawa Tengah mengacu pada Undang-Undang No 2 Tahun 2002 Tentang Kepolisian, Peraturan disiplin anggota Polri diatur melalui Peraturan Pemerintah No. 2 Tahun 2003, Kode Etik Profesi Polri yang diatur dalam Peraturan Kapolri Nomor 14 Tahun 2011. Apabila di sidang kode etik terbukti bersalah maka dilakukan peradilan umum dengan mengacu pada undang-undang narkotika No. 35 Tahun 2009 dan Kitab Undang-Undang Hukum Acara Pidana (KUHAP) dalam penyidikan terhadap tindak pidana.
\end{abstract}

Kata kunci : Kode Etik; Kepolisian; Pidana Narkoba

\section{THE AUTHORITY OF THE POLRI IN ENFORCING THE OFFICER'S ETHICS CODE THAT DO DRUG CRIMINAL ACTION}

\begin{abstract}
The purpose of this research is to examine the authority of the National Police in enforcing the code of ethics for members of the Police who commit drug crimes. 14 of 2011 concerning the Police Code of Ethics and how to reposition the authority of the National Police in enforcing the code of ethics for members of the Police who commit drug crimes, a review of the Chief of Police Regulation No. 14 of 2011 concerning the Police Code of Ethics. The method in this study used a qualitative descriptive research method with a normative juridical approach. The results of this study are: The Police Code of Ethics as stipulated in the Chief of Police Regulation Number 14 the Year 2011 has been functioning towards members of the police as law enforcement officers. So that with the functioning of the police code of ethics, it can suppress violations of the police code of ethics relating to state ethics, institutional ethics, social ethics, and personality ethics, and each member of the police must submit. The authority of the Central Java Regional Police in enforcing the code of ethics for members of the Police who commit drug crimes through a code of ethics trial and if proven to be carried out by a general court and dismissal from the police service if proven to have committed drug crimes. committing a drug crime, the Central Java Regional Police refers to Law No. 2 of 2002 concerning the Police, the disciplinary regulations for Polri members are regulated through Government Regulation No. 2 of 2003, the National Police's Professional Code of Ethics which is regulated in the National Police Chief Regulation No. 14 of 2011. If the code of ethics is proven guilty at trial, a general court is conducconcerninge to the Narcotics Law No. 35 of 2009 and the Criminal Procedure Code (KUHAP) in investigating criminal acts.
\end{abstract}

Keywords: Code of Ethics; Police; Narcotics Criminal 
e-ISSN : 2621-4105

\section{A. PENDAHULUAN}

Lembaga Kepolisian Negara Republik Indonesia memiliki etika profesi dalam melaksanakan wewenangnya demi tercapainya tugas dan fungsi pemerintahan dari kepolisian itu sendiri. Etika profesi itu ada untuk menciptakan kepolisian sebagai aparat penegak hukum yang profesional, memiliki kredibilitas, serta beretika. ${ }^{1}$

Polisi merupakan aparat penegak hukum yang berkewajiban dalam mewujudkan keamanan dan kenyamanan dalam kehidupan bermasyarakat, kepolisian merupakan lembaga pengayoman masyarakat dalam segala kondisi sosial, diatur dalam Undangundang No 2 Tahun 2002 Tentang Kepolisian. Peran kepolisian dapat dikatakan sebagai aspek kedudukan yang berhubungan dengan kedudukannya sebagai pelindung masyarakat. Pada kenyataanya sebagian anggota bertindak sebaliknya dan tidak sesuai dengan etika profesi kepolisian atau dalam kata lain polisi melakukan pelanggaran terhadap kode etik kepolisian. Hal ini tentunya berakibat hukum dan dapat mengakibatkan terjadinya tindak pidana. ${ }^{2}$

Kompleksitas tantangan tugas Polri pada era reformasi dalam perjalanannya selain telah memberi manfaat bagi Polri dengan berbagai kemajuan yang signifikan baik di bidang pembangunan kekuatan, pembinaan maupun operasional. Namun di sisi lain diakui secara jujur terdapat akses negatif dari penyelenggaraan tugas pokoknya berupa penyimpangan perilaku anggota Polri seperti penyalahgunaan kekuasaan / wewenang (abuse of power), dan melakukan perbuatan tercela lainnya yang melangggar kaidah-kaidah moral, sosial dan keagamaan. Penyimpangan perilaku anggota Polri tersebut di atas adalah merupakan pelanggaran terhadap peraturan disiplin anggota Polri sebagaimana yang diatur dalam Undang-Undang No 2 Tahun 2002 Tentang Kepolisian, turunannya mengenai disiplin diatur dalam Peraturan Pemerintah Republik Indonesia Nomor 2 Tahun 2003 tentang Peraturan Disiplin Anggota Polri.

Guna menjamin kemampuan profesi kepolisian dalam pelaksanaan tugas dan fungsinya, disebutkan dalam Pasal 32 Undang-Undang Nomor 2 Tahun 2002, bahwa: ${ }^{3}$ "pembinaan kemampuan profesi pejabat Kepolisian Negara Republik Indonesia diselenggarakan melalui pembinaan etika profesi dan pengembangan pengetahuan serta pengalamannya di bidang teknis kepolisian melalui pendidikan, pelatihan, dan penugasan secara berjenjang dan berlanjut."

Kode etik profesi Kepolisian Negara Republik Indonesia pada dasarnya merupakan pedoman bagi pengemban fungsi kepolisian lainnya dalam melaksanakan tugas sesuai dengan peraturan perundang-undangan yang berlaku di lingkungannya, oleh karena itu kode etik profesi memiliki peranan penting dalam mewujudkan polisi yang profesional. ${ }^{4}$

\footnotetext{
${ }^{1}$ Lundu Harapan Situmorang, "Fungsi Kode Etik Kepolisian Dalam Mencegah Penyalahgunaan Wewenang Sebagai Aparat Penegak Hukum”, Jurnal Fakultas Hukum Universitas Atmajaya Yogyakarta (2016)

2 Nozel Saparingka, "Penyelesaian Pelanggaran Kode Etik Kepolisian Berpotensi Pidana", Jurnal, Fakultas Hukum Universitas Atmajaya Jogyakarta, (2016)

${ }^{3}$ Undang-Undang Nomor 2 Tahun 2002 Tentang Kepolisian Republik Indonesia

${ }^{4}$ Petrus Kanisius Noven M, "Fungsi Kode Etik Profesi Polisi Dalam Rangka Meningkatkan Profesionalisme Kinerjanya”, Fakultas Hukum Universitas Atmajaya Jogyakarta, 2014
} 
Kode etik bagi profesi Kepolisian tidak hanya didasarkan pada kebutuhan profesional, tetapi juga telah diatur secara normatif dalam Undang Undang No. 2 Tahun 2002 tentang Kepolisian Negara Republik Indonesia yang ditindaklanjuti dengan Peraturan Kapolri, sehingga kode etik profesi polri berlaku mengikat bagi setiap anggota Polri. ${ }^{5}$ Pelanggaran hukum atau tindak pidana Narkoba yang dilakukan oleh oknum anggota Polisi di Polda Jawa Tengah akan diproses sesuai dengan aturan yang berlaku yaitu Undang-Undang Nomor 2 Tahun 2002 Tentang Kepolisian Republik Indonesia, Peraturan Pemerintah No 2 Tahun 2003 Tentang Peraturan Disiplin Anggota Kepolisian Negara Republik Indonesia dan Peraturan Kapolri No 14 Tahun 2011 Tentang Kode Etik Profesi Kepolisian Negara Republik Indonesia.

Penelitian sebelumnya yang relevan dengan penelitian ini pernah diangkat oleh Pradana (2016). Penelitian tersebut berjudul "Proses Peradilan Terhadap Anggora Polri Yang Melakukan Tindak Pidana." Penelitian ini lebih fokus mengkaji bagaimana tata cara proses peradilananggota Polri yang melakukan pelanggaran tindak pidana. Apakah ada perbedaan proses peradilan anggota Polri dengan masyarakat sipil. Selain itu penelitian ini hanya fokus mengkaji tentang tata cara proses peradilan terhadap tindak pidana yang dilakukan oleh anggota Polri dengan masyarakat biasa. ${ }^{6}$

Sedangkan penelitian oleh Widodo (2018) mengangkat permasalahan bagaimana penegakan hukum terhadap anggota kepolisian yang menyalahgunakan narkotika dan psikotropika, bagaimana pengaturan dan sanksi pidana terhadap Polri pelaku tindak pidana narkotika, serta bagaimana penerapan sanksi pidana dan kode etik terhadap Polri sebagai pelaku tindak pidana narkotika. Hasil dari penelitian ini menjelaskan bahwa proses penegakan hukum terhadap anggota Polri yang terlibat kasus tindak pidana Narkoba telah dijatuhi sanksi sesuai dengan ketentuan yang berlaku di internal Polri. Sedangkan anggota Polri yang terlibat pelanggaran kode etik belum dapat dilaksanakan secara maksimal dan tegas walaupun dalam proses pengadilan sudah dinyatakan bersalah. $^{7}$

Penelitian yang dilakukan oleh Darmika (2019) yang berjudul "Penegakan Hukum terhadap Anggota Polri yang Melakukan Tindak Pidana Narkotika”, dari hasil penelitian tersebut menyimpulkan perkara penyelesaian Narkotika yang dilakukan oleh kepolisian sama dengan masyarakat pada umumnya yaitu melalui peradilan umum. Pertama, penyelesaian melalui peradilan umum oleh aparat penegak hukum dalam proses penyelidikan dan penyidikan, penyelesaian dan penyerahan berkas perkara kepada jaksa penuntut umum, pemeriksaan dalam proses persidangan, dan pelaksanaan putusan yang dilakukan oleh aparat penegak hukum baik kepolisian, jaksa, hakim dalam penegakan terhadap anggota polisi yang melakukan tindak pidana Narkoba telah sesuai dengan undang-undang. Kedua, selain peradilan umum anggota polisi yang melakukan tindak

\footnotetext{
${ }^{5}$ Suwarni, "Perilaku Polisi”, Nusa Media, (2009):5.

${ }^{6}$ Dwi Indah Widodo, "Penegakan Hukum Terhadap Anggota Kepolisian Yang Menyalahgunakan Narkotika Dan Psikotropika”, Jurnal Magnum Opus 1, (1): 1, 2018

${ }^{7}$ Eflando Cahaya Chandan Pradana,"Proses Peradilan Terhadap Anggota Polri Yang Melakukan Tindak Pidana”, Varia Justicia 12 (1), 2016
} 
pidana juga akan ada tambahan lain yaitu dari internal kepolisian sendiri yang berupa penegakan hukum melalui sidang kode etik polisi. ${ }^{8}$

Penelitian ini melengkapi penelitian sebelumnya yang banyak membahas tentang pelanggaran kode etik pada anggota Polri yang melakukan tindak pidana Narkoba. Perbedaan penelitian ini dari penelitian sebelumnya adalah bagaimana dalam penelitian ini meneliti tentang penanganan pelanggaran kode etik terhadap anggota Kepolisian yang melakukan tindak pidana Narkoba suatu kajian Peraturan Kapolri No. 14 Tahun 2011 Tentang Kode Etik Kepolisian. Dari hal tersebut dapat menjelaskan bahwa penelitian ini berbeda dengan penelitian sebelumnya. Tujuan penelitian ini adalah untuk mengkaji bagaimana kewenangan Polri dalam menegakkan kode etik anggota Polri yang melakukan tindak pidana Narkoba suatu kajian Peraturan Kapolri No. 14 Tahun 2011 Tentang Kode Etik Kepolisian, bagaimana reposisi kewenangan Polri dalam menegakkan kode etik anggota Polri yang melakukan tindak pidana Narkoba suatu kajian Peraturan Kapolri No. 14 Tahun 2011 Tentang Kode Etik Kepolisian.

\section{B. PERMASALAHAN}

Berdasarkan latar belakang tersebut, maka perumusan masalah dalam artikel ini adalah : Bagaimana kewenangan Polri dalam menegakkan kode etik anggota Polri yang melakukan tindak pidana Narkoba suatu kajian Peraturan Kapolri No. 14 Tahun 2011 Tentang Kode Etik Kepolisian? Bagaimana reposisi kewenangan Polri dalam menegakkan kode etik anggota Polri yang melakukan tindak pidana Narkoba?

\section{METODE PENELITIAN}

Metode penelitian yang dipakai yaitu yuridis normatif. Menurut Soerjono Soekanto pendekatan yuridis normatif yaitu penelitian hukum yang dilakukan dengan cara meneliti bahan pustaka atau data sekunder sebagai bahan dasar untuk diteliti dengan cara mengadakan penelusuran terhadap peraturan-peraturan dan literatur-literatur yang berkaitan dengan permasalahan yang diteliti ${ }^{9}$ Sifat penelitian ini disesuaikan dengan masalah yang dipergunakan penelitian yang bersifat deskriptif analitis, yaitu menggambarkan yang jelas, rinci dan sistematis tentang objek yang diteliti. Analitis artinya data yang diperoleh akan dianalisis untuk pemecahan terhadap permasalahan sesuai dengan ketentuan hukum yang berlaku. Hal utama yang ingin didiskripsikan adalah kewenangan Polri dalam menegakkan kode etik anggota Kepolisian yang melakukan tindak pidana Narkoba suatu kajian Peraturan Kapolri No. 14 Tahun 2011 Tentang Kode Etik Kepolisian.

Teori yang dipakai dalam penulisan artikel ini adalah teori penegakan hukum. Pengertian penegakan hukum dapat juga diartikan penyelenggaraan hukum oleh petugas penegak hukum dan oleh setiap orang yang mempunyai kepentingan sesuai dengan kewenangannya masing-masing menurut aturan hukum yang berlaku. Penegakan hukum pidana merupakan satu kesatuan proses diawali dengan penyidikan,

\footnotetext{
${ }^{8}$ Gede Arya Aditya Darmika, "Penegakan Hukum terhadap Anggota Polri yang Melakukan Tindak Pidana Narkotika", Jurnal Analogi Hukum, 1 (1) 2019

${ }^{9}$ Soerjono Soekanto \& Sri Mamudji, "Penelitian Hukum Normatif (Suatu Tinjauan Singkat)”, Rajawali Pers, Jakarta, (2001):13
} 
penangkapan, penahanan, peradilan terdakwa dan diakhiri dengan pemasyarakatan terpidana. ${ }^{10}$

Menurut Soerjono Soekanto, mengatakan bahwa penegakan hukum adalah "kegiatan menyerasikan hubungan nilai-nilai yang terjabarkan dalam kaidah-kaidah mantap dan sikap tindak sebagai rangkaian penjabaran nilai tahap akhir. Untuk menciptakan, memelihara dan mempertahankan kedamaian pergaulan hidup". ${ }^{11}$ Menurut Moeljatno menguraikan berdasarkan dari pengertian istilah hukum pidana yang mengatakan bahwa "penegakan hukum adalah bagian dari keseluruhan hukum yang berlaku disuatu negara yang mengadakan unsur-unsur dan aturan-aturan", yaitu: ${ }^{12}$ "Menentukan perbuatan-perbuatan yang tidak boleh di lakukan dengan di sertai ancaman atau sanksi berupa pidana tertentu bagi barang siapa yang melanggar larangan tersebut, menentukan dan dalam hal apa kepada mereka yang melanggar larangan-larangan itu dapat dikenakan atau dijatuhi pidana sebagaimana yang telah diancamkan, menentukan dengan cara bagaimana pengenaan pidana itu dapat dilaksanakan apabila orang yang disangkakan telah melanggar larangan tersebut".

\section{HASIL DAN PEMBAHASAN}

\section{Kewenangan Polri Dalam Menegakkan Kode Etik Anggota Kepolisian Yang Melakukan Tindak Pidana Narkoba}

Narkoba menjadi suatu ancaman dan bahaya dalam masyarakat bila kurang waspada, dapat menjadi bencana yang bisa saja menimpa kita. Sebagai suatu pembanding, dapat kita rasakan betapa serius dan kompleksnya musibah bencana alam yang akhir-akhir ini terjadi di tanah air. Mengingatkan kepada kita tentang perlunya manajemen yang handal dalam menghadapi suatu bencana masal, tentu termasuk bencana bahaya akibat Narkoba. ${ }^{13}$

Oknum Polri yang menyalahgunakan narkotika diberlakukan Undang-Undang No. 35 Tahun 2009 tentang Narkotika. Selain sanksi pidana yang tercantum pada UndangUndang No.35 Tahun 2009, kepada oknum Polri yang menyalahgunakan Narkotika juga diberikan sanksi administratif yakni sanksi yang diberikan oleh instansi yang bersangkutan. Oknum polisi yang menggunakan narkotika berarti telah melanggar aturan disiplin dan kode etik karena setiap anggota polri wajib menjaga tegaknya hukum serta menjaga kehormatan, reputasi, dan martabat Kepolisian Republik Indonesia. Pelanggaran terhadap aturan disiplin dan kode etik akan diperiksa dan bila terbukti akan dijatuhi sanksi.

Penjatuhan sanksi disiplin serta sanksi atas pelanggaran kode etik tidak menghapus tuntutan pidana terhadap anggota polisi yang bersangkutan (Pasal 12 ayat (1) PP 2/2003 jo.Pasal 28 ayat (2) Perkapolri Nomor 14 Tahun 2011). Oleh karena itu, oknum polisi yang menggunakan narkotika tetap akan diproses hukum acara pidana walaupun telah menjalani sanksi disiplin dan sanksi pelanggaran kode etik

\footnotetext{
${ }^{10}$ Harun M.Husen, “Kejahatan dan Penegakan Hukum Di Indonesia”, Rineka Cipta, Jakarta, (1990):58

${ }^{11}$ Soerjono Soekanto, "Faktor-Faktor Yang Mempengaruhi Penegakan Hukum”, UI Pres, Jakarta, (1983): 35

${ }^{12}$ Moeljatno, "Asas-Asas Hukum Pidana”, Putra Harsa, Surabaya, (1993):23

${ }^{13}$ Fuad Alghi Fari,Susi Fitria Dewi, "Faktor Penyebab Terjadinya Tindak Pidanakejahatan Narkotika”, Jurnal USM Law Review 4, no 1 (2021): 438-439. http://dx.doi.org/10.26623/julr.v4i1.3350
} 
Dalam Perkap Nomor 14 Tahun 2011 Tentang Kode Etik Profesi Polri Pasal 21 dijelaskan bahwa ada tujuh (7) jenis sanksi pelanggaran Kode Etik Profesi Polri dimana anggota Polri yang dinyatakan sebagai Pelanggar sebagaimana dimaksud dalam Pasal 20 ayat (2) Peraturan Kapolri Nomor 14 tahun 2011 tentang Kode Etik Profesi Kepolisian Negara Republik Indonesia. Sanksi seperti perilaku pelanggar dinyatakan sebagai perbuatan tercela, mengikuti pembinaan mental kepribadian, kejiwaan, keagamaan dan pengetahuan profesi, dipindah tugaskan ke jabatan berbeda dan PTDH sebagai anggota Polri.

Selain diatur dalam peraturan kode etik profesi Polri, tingkah laku anggota juga diatur dalam peraturan disiplin yang harus ditaati. Apabila anggota tersebut melanggar peraturan disiplin maka anggota akan dikenakan sanksi disiplin sesuai dengan yang diamanatkan dalam PP No 2 tahun 2003 tentang Peraturan Disiplin Anggota Kepolisian Negara Republik Indonesia. Bagi anggota yang melanggar peraturan disiplin maka dapat dikenakan sanksi berupa tindakan disiplin atau hukuman disiplin. ${ }^{14}$

Kode Etik Kepolisian berfungsi sebagai pedoman terhadap anggota kepolisian selaku aparat penegak hukum di wilayah hukum Polda Jawa Tengah. Sehingga dengan berfungsinya kode etik kepolisian tersebut maka bisa menekan pelanggaran-pelanggaran terhadap kode etik kepolisian yang berkaitan dengan etika kenegaraan, etika kelembagaan, etika kemasyarakatan dan etika kepribadian.dan setiap anggota kepolisian tersebut harus tunduk pada Kode etik Kepolisian.

Kewenangan Kepolisian Daerah Jawa Tengah dalam menegakkan kode etik anggota Kepolisian yang melakukan tindak pidana Narkoba melalui sidang kode etik dan apabila terbukti dilakukan peradilan umum serta pemecatan dari dinas kepolisian apabila terbukti melakukan tindak pidana Narkoba.

\section{Reposisi Kewenangan Polri Dalam Menegakkan Kode Etik Anggota Kepolisian Yang Melakukan Tindak Pidana Narkoba}

Secara yuridis, sebagaimana diatur`dalam ketentuan UU No. 2 Tahun 2002 tentang Kepolisian secara gambling dirumuskan bahwa tugas pokok Polri adalah sebagai penegak hukum, sebagai pelindung, sebagai pengayom dan pembimbing masayarakat terutama dalam rangka kepatuhan dan ketaatan pada hukum yang berlaku. Undang-undang terseut menhatut tentang tiga hal mendasar yang menjadi tugas utama Polri sebagaimana yang termuat dalam Tribrata maupun Catur Prasetya Polri. Ketentuan tersebut diatur dalam Pasal 13 yang menyatakan bahwa Polri bertugas:1.memelihara keamanan dan ketertiban masyarakat; 2. menegakkan hukum; 3. memberikan perlindungan, pengayoman dan pelayanan kepada masyarakat. ${ }^{15}$

Oknum aparat polisi yang terseret tindak pidana dilakukan proses penegakan Kode Etik di kepolisian yang terdapat pengaturannya dalam "Perkap Nomor 14 Tahun 2011 tentang Kode Etik Profesi Polri (PERKAP KEPP)." Dalam "Pasal 17 ayat 1 Perkap Nomor 14 Tahun 2011 tentang Kode Etik Profesi. Penegakan kode etik dilakukan oleh

\footnotetext{
${ }^{14}$ Warsito Hadi Utomo, "Hukum Kepolisan Di Indonesia", Prestasi Pustaka, Jakarta, (2005):174.

${ }^{15}$ Ryanto Ulil Anshar, Joko Setiyono, "Tugas dan Fungsi Polisi Sebagai Penegak HukumdalamPerspektif Pancasila”, Jurnal Pembangunan Hukum Indonesia 2, (3): 359-372. 2020. https://doi.org/10.14710/jphi.v2i3.359-372
} 
Propam Polri, Komisi Kode Etik Profesi (KKEP), Komisi Banding, Pengembangan Fungsi Hukum Polri, SDM Polri. Terkait dengan anggota polisi yang melakukan tindak pidana narkotika, orang tersebut juga melanggar Kode Etik Profesi Polisi (KEPP), ketika polisi melakukan tindak pidana narkotika yang diutamakan proses peradilan umum. "Sementara itu polisi yang melakukan tindak pidana narkotika itu diproses hingga ada putusan pengadilan yang tetap."

Pada dasarnya undang-undang narkotika menganut konsep strict liability mengandung unsur pertanggungjawaban mutlak. Artinya setiap orang yang memenuhi unsur-unsur pidana pada undang-undang narkotika dapat dipertanggungjawabkan secara mutlak. Sesuai tujuannya undang-undang narkotika sebagai yang tertuang dalam Pasal 4 UU Narkotika. Pasal tersebut bermakna bahwa keberadaan UU Narkotika dijadikan wadah utama untuk menyelamatkan Indonesia dari maraknya penyalahguna narkotika yakni dengan menjamin, dan mencegah penyebaran penyalahguna narkotika. ${ }^{16}$

Dengan merujuk pada bunyi Pasal 29 ayat (1) Undang-Undang Nomor 2 Tahun 2002 tentang Kepolisian Negara Republik Indonesia tersebut diatas maka nyatalah kiranya anggota kepolisian yang melakukan tindak pidana adalah diperiksa (disidik) oleh anggota kepolisian sendiri yang tugas dan fungsinya sebagai penyidik sebagaimana halnya anggota masyarakat sipil lainnya yang melakukan tindak pidana, kecuali apabila Anggota kepolisian itu melakukan tindak indisipliner maka hal tersebut diperiksa (disidik) oleh atasan lansungnya setelah anggota kepolisian tersebut diperiksa berdasarkan Kode Etik Profesi Kepolisian sebagaimana yang diatur dalam Pasal 34 dan Pasal 35 Undang-Undang Nomor 2 Tahun 2002 tentang Kepolisian Negara Republik Indonesia.

Kewenangan Kepolisian Daerah Jawa Tengah dalam menegakkan kode etik anggota Kepolisian yang melakukan tindak pidana Narkoba memiliki dua landasan utama yaitu melalui keberadaan peraturan disiplin dan kode etik profesi.

1. Peraturan disiplin anggota Polri diatur melalui PP No. 2 Tahun 2003.

2. Landasan kedua adalah Kode Etik Profesi Polri yang diatur dalam Peraturan Kapolri Nomor 14 Tahun 2011.

Reposisi Kewenangan Kepolisian dalam menegakkan kode etik Kepolisian didasarkan pada Undang-Undang No 2 Tahun 2002 tentang Kepolisian, peraturan Kepolisian No 14 Tahun 2011 tentang Kode etik Kepolisian dan Peraturan Pemerintah No 2 Tahun 2003 tentang Disiplin Anggota Kepolisian. Apabila terjadi pelanggaran kumulatif antara pelanggaran disiplin dan pelanggaran Kode Etik Profesi Polri, maka penyelesaiannya dilakukan melalui sidang disiplin atau Sidang Komisi Kode Etik Polri berdasarkan pertimbangan atasan Ankum dari terperiksa dan pendapat serta saran hukum dari pengemban fungsi pembinaan hukum. Penanganan pelanggaran Kode Etik Profesi

\footnotetext{
${ }^{16}$ Deni Setya Bagus Yuherawan, Baiq Salimatul Rosdiana,"Ketidaktepatan Penjatuhan Pidana Penjara Terhadap Penyalahguna Narkotika", Jurnal Ius Constituendum 5, $\quad$ (2): 177-195, 2020. http://dx.doi.org/10.26623/jic.v5i2.2207
} 
Polri dilakukan jika ada laporan atau pengaduan yang diajukan oleh masyarakat, anggota Polri atau sumber lain yang dapat dipertanggungjawabkan.

Polisi yang melakukan tindak pidana Narkoba dan telah diputus oleh pengadilan terbukti bersalah maka sesuai dengan dengan Pasal 1 angka 17 yaitu: "Pemberhentian tidak dengan hormat yang selanjutnya di singkat dengan PTDH adalah pengakhiran masa dinas kepolisian oleh pejabat yang berwenang terhadap seorang anggota polri karena telah terbukti melakukan pelanggaran KEPP, profesi dan/ atau tindak pidana." Terkait dengan anggota polisi yang melakukan tindak pidana Narkoba, orang tersebut juga melanggar kode etik polisi, ketika polisi melakukan tindak pidana Narkoba yang diutamakan proses peradilan umum. Sementara itu polisi yang melakukan tindak pidana Narkoba itu diproses hingga ada putusan pengadilan yang tetap. Jika setelah menjalani putusan baru satuan mengambil tindakan yang akan menilai adalah pimpinan atau juga disebut Ankum. ${ }^{17}$

\section{E. PENUTUP}

Kode Etik Kepolisian sebagaimana diatur dalam Peraturan Kapolri Nomor 14 Tahun 2011 sudah berfungsi terhadap anggota kepolisian selaku aparat penegak hukum. Sehingga dengan berfungsinya kode etik kepolisian tersebut maka bisa menekan pelanggaran-pelanggaran terhadap kode etik kepolisian yang berkaitan dengan etika kenegaraan, etika kelembagaan, etika kemasyarakatan dan etika kepribadian.dan setiap anggota kepolisian tersebut harus tunduk. Kewenangan Kepolisian Daerah Jawa Tengah dalam menegakkan kode etik anggota kepolisian yang melakukan tindak pidana Narkoba melalui sidang kode etik dan apabila terbukti dilakukan peradilan umum serta pemecatan dari dinas kepolisian apabila terbukti melakukan tindak pidana Narkoba. Reposisi terhadap penegakan hukum terhadap anggota Kepolisian yang melanggar kode etik dengan melakukan tindak pidana Narkoba, Kepolisian Daerah Jawa Tengah mengacu pada Undang-Undang No 2 Tahun 2002 tentang Kepolisian, peraturan disiplin anggota Polri diatur melalui PP No. 2 Tahun 2003, Kode Etik Profesi Polri yang diatur dalam Peraturan Kapolri Nomor 14 Tahun 2011. Apabila di sidang kode etik terbukti bersalah maka dilakukan peradilan umum dengan mengacu pada Undang-Undang Narkotika No. 35 Tahun 2009 dan Kitab Undang-Undang Hukum Acara Pidana (KUHAP) dalam penyidikan terhadap tindak pidana.

\section{DAFTAR PUSTAKA}

Gede Arya Aditya Darmika, Penegakan Hukum terhadap Anggota Polri yang Melakukan Tindak Pidana Narkotika, Jurnal Analogi Hukum, 1 no 1 (2019)

Eflando Cahaya Chandan Pradana, Proses Peradilan Terhadap Anggota Polri Yang Melakukan Tindak Pidana, Varia Justicia 12 no 1 (2016)

Deni Setya Bagus Yuherawan, Baiq Salimatul Rosdiana, "Ketidaktepatan Penjatuhan Pidana Penjara Terhadap Penyalahguna Narkotika”, Jurnal Ius Constituendum 5, (2): 177-195, 2020. http://dx.doi.org/10.26623/jic.v5i2.220

${ }^{17}$ Krisna Monita Sari, "Penegakan Hukum terhadap Anggota Polri yang Melakukan Tindak Pidana Narkoba", Jurnal Logika 10 no 1 (2019): 56. https://doi.org/10.25134/logika.v10i01.2181 
Dwi Indah Widodo, "Penegakan Hukum Terhadap Anggota Kepolisian Yang Menyalahgunakan Narkotika Dan Psikotropika", Jurnal Magnum Opus 1, no 1, (2018); 1

Dwi Oknerison, Penegakan Kode Etik Profesi Terhadap Perilaku Anggota Kepolisian Dalam Menangani Perkara, Jurnal Lex et Societatis 2(6), 2014.

Fitra Octoriny, Penerapan Hukuman Disiplin Terhadap Anggota Kepolisian Negara Republik Indonesia Yang Melakukan Nikah Siri Oleh Provos Di Polda Sumbar, Jurnal Normative 7 (1), 2017.

Fuad Alghi Fari,Susi Fitria Dewi, "Faktor Penyebab Terjadinya Tindak Pidanakejahatan Narkotika", Jurnal USM Law Review 4, no 1 (2021): 438-439). http://dx.doi.org/10.26623/julr.v4i1.3350

Lundu Harapan Situmorang, Fungsi Kode Etik Kepolisian Dalam Mencegah Penyalahgunaan Wewenang Sebagai Aparat Penegak Hukum, Jurnal,Fakultas Hukum Universitas Atmajaya Yogyakarta, 2016.

Harun M.Husen, "Kejahatan dan Penegakan Hukum Di Indonesia", Rineka Cipta, Jakarta, 1990.

Krisna Monita Sari, "Penegakan Hukum terhadap Anggota Polri yang Melakukan Tindak Pidana Narkoba", Jurnal Logika 10 no 1 (2019):56. https://doi.org/10.25134/logika.v10i01.2181

Moeljatno, "Asas-Asas Hukum Pidana”, Putra Harsa, Surabaya, 1993.

Nozel Saparingka, "Penyelesaian Pelanggaran Kode Etik Kepolisian Berpotensi Pidana”, Jurnal, Fakultas Hukum Universitas Atmajaya Jogyakarta, 2016.

Peraturan Kepolisian No 14 Tahun 2011 Tentang Kode etik Kepolisian

Petrus Kanisius Noven M, Fungsi Kode Etik Profesi Polisi Dalam Rangka Meningkatkan Profesionalisme Kinerjanya, Fakultas Hukum Universitas Atmajaya Jogyakarta, 2014

Ryanto Ulil Anshar, Joko Setiyono, "Tugas dan Fungsi Polisi Sebagai Penegak HukumdalamPerspektif Pancasila”, Jurnal Pembangunan Hukum Indonesia 2, (3): 359-372. 2020. https://doi.org/10.14710/jphi.v2i3.359-372

Soerjono Soekanto, "Faktor-Faktor Yang Mempengaruhi Penegakan Hukum", UI Pres, Jakarta, 1983.

Soerjono Soekanto \& Sri Mamudji, "Penelitian Hukum Normatif (Suatu Tinjauan Singkat)", Rajawali Pers, Jakarta,2001

Warsito Hadi Utomo, “Hukum Kepolisan Di Indonesia”, Prestasi Pustaka, Jakarta, 2005

Undang-Undang No 2 Tahun 2002 Tentang Kepolisian 